\title{
The appearance and characteristics of early pregnancy factor in the pig
}

\author{
Halle Morton*, D. J. Morton† and F. Ellendorff \\ Institut Fur Tierzucht und Tierverhalten, Mariensee, 3057 Neustadt 1, West Germany
}

\begin{abstract}
Summary. The occurrence of early pregnancy factor in the pig has been established by the rosette inhibition test and by the criteria that gel filtration of serum resulted in a number of peaks of activity similar to those observed in other species. In the pig EPF is present virtually to the end of pregnancy, with a biphasic production in which the titres of EPF decline markedly in mid-pregnancy. Free EPF-A appears concurrently with EPF in the first 3 weeks of pregnancy in some but not all pigs. The presence of excess EPF-A has an inhibitory effect in the rosette inhibition test and modifications, including an initial serum dialysis step, have been introduced into the test to take account of this inhibitory effect.
\end{abstract}

\section{Introduction}

Early pregnancy factor (EPF) is a pregnancy-dependent protein complex which has been detected in the serum of all species so far tested including mouse, man and sheep (Morton, Hegh \& Clunie, 1976; Morton, Rolfe, Clunie, Anderson \& Morrison, 1977; Morton, Nancarrow, Scaramuzzi, Evison \& Clunie, 1979a). The assay for the detection of EPF is the rosette inhibition test, originally devised to test the immunosuppressive potential of antilymphocyte serum (Bach, Dormont, Dardenne \& Balner, 1969). These authors found that some preparations of antilymphocyte serum had the ability to inhibit spontaneous (Bach et al., 1969), sometimes called active (Felsburg, Edelman \& Gilman, 1976), rosettes formed between lymphocytes and heterologous red blood cells. As applied to the detection of EPF, less antilymphocyte serum is required to inhibit rosette formation if lymphocytes have previously been treated with EPF. As a consequence of the indirect character of the rosette inhibition test, it is essential, when establishing the presence of EPF in a species not previously investigated, to demonstrate that any increase in the rosette inhibition titre (RIT) is in fact due to a substance with properties the same as or similar to those of EPF in the species already examined.

Studies of mouse, sheep and human EPF have resulted its partial characterization (Morton et al., 1980; Clarke \& Wilson, 1982; Rolfe, Morton \& Clarke, 1983). One of the principal characteristics of EPF established in other species is its occurrence after gel filtration as a multimolecular weight substance either free or in association with a protein carrier (Clarke, Morton, Rolfe \& Clunie, 1980). EPF itself may be dissociated into two separate moieties termed EPF-A and EPF-B which have separate sites of synthesis in vivo (Morton et al., 1980). EPF-A is formed in the oviduct

* Present address: Department of Surgery, Princess Alexandra Hospital, University of Queensland, Brisbane, Queensland 4102, Australia.

$\dagger$ Present address: CSIRO Division of Food Research, Meat Research Laboratory, Cannon Hill, Queensland 4170, Australia. 
during oestrus and pregnancy; production of EPF-B by the ovary, however, is associated only with pregnancy and is a result of the combined action of signals from the pituitary and the zygote (Cavanagh, Morton, Rolfe \& Gidley-Baird, 1982). EPF-A and EPF-B are both required for EPF activity (Clarke et al., 1980).

The objectives of this investigation were (1) to establish the appropriate conditions for the rosette inhibition test in the pig, (2) to determine whether EPF with its characteristic physical properties is present in the pregnant sow and (3) if detected, to follow the time course of EPF production throughout pregnancy.

\section{Materials and Methods}

Animals. German Landrace gilts and sows of the Institute stock were housed under normal daylight conditions at the experimental farm. A standard pelleted pig chow and water were provided twice daily. As a routine procedure, all sows were tested daily for the occurrence of oestrus and were mated with an intact boar on the morning of Day 1 or Day 2 of oestrus. Subsequently, animals were tested daily for the recurrence of oestrus to indicate failure to establish pregnancy. Blood samples were collected from an ear vein of unrestrained animals as described previously (Hultsch \& Ellendorff, 1979). Two groups of animals were tested in this investigation. (1) In Group 1, of 20 animals, random blood samples $(2-3 \mathrm{ml})$ were collected into dry tubes in the first 2 weeks after mating; control samples were collected from unmated sows at various stages of oestrus. (2) In Group 2, of 10 animals, blood was collected at $2 \mathrm{~h}, 1$ and 2 days and 1, 2, 3, 8, 12 and 14 weeks after mating. Blood was also collected from 2 animals 1 week after parturition.

Serum. Blood samples from sows for assay of EPF were allowed to clot, the serum removed, incubated at $56^{\circ} \mathrm{C}$ for $0.5 \mathrm{~h}$, then frozen in $0.5 \mathrm{ml}$ amounts at $-30^{\circ} \mathrm{C}$. Samples were only thawed once before testing.

Lymphocytes. Blood $(40 \mathrm{ml})$ was obtained from a chronic jugular catheter (Ellendorfi, Parvizi, Elsaesser \& Smidt, 1977) in castrated male pigs, mixed with $4 \times 10^{3}$ units preservative-free heparin (Serva, Heidelberg, West Germany) and maintained at room temperature. The blood was diluted to 2 parts with $0.9 \%(\mathrm{w} / \mathrm{v}) \mathrm{NaCl}$, mixed and $15 \mathrm{ml}$ layered carefully on top of $12 \mathrm{ml}$ Lymphodex (Fresenius, West Germany) being very careful not to disturb the interface. After centrifugation at $1000 \mathrm{~g}$ for $20 \mathrm{~min}$, the lymphocyte layer was removed, the cells washed twice in Hanks' balanced salt solution without calcium or magnesium (BSS; Serva) and made up to a final volume to contain $1.5 \times 10^{4}$ cells $/ \mu 1$ BSS. Cells were prepared daily for the assay.

Antilymphocyte serum. Lymphocytes were obtained from the spleens of freshly killed male pigs, by the method described previously (Morton et al., 1979a). The lymphocytes were made up to $10^{9}$ cells $/ \mathrm{ml}$ in $0.9 \% \mathrm{NaCl}$, suspended in an equal volume of Freund's complete adjuvant (Difco, Detroit) and injected subcutaneously at multiple sites into outbred rabbits. After 1 month, intravenous injections, each of $10^{9}$ cells in $0.5 \mathrm{ml} 0.9 \%(\mathrm{w} / \mathrm{v}) \mathrm{NaCl}$, were given on 3 consecutive days; 10 days later the animals were bled from the ear vein into dry bottles. The serum was harvested, inactivated at $56^{\circ} \mathrm{C}$ for $0.5 \mathrm{~h}$, dispensed into $2 \mathrm{ml}$ lots and then frozen. One sample was dispensed into $20 \mu \mathrm{l}$ lots, frozen and a $20 \mu \mathrm{l}$ sample thawed each day for use in the assay.

Sheep red blood cells. Blood $(20 \mathrm{ml})$ was collected into preservative-free heparin $\left(2 \times 10^{3}\right.$ units $)$ from the jugular vein of a non-pregnant sheep and stored at $8^{\circ} \mathrm{C}$. The blood was obtained fresh at weekly intervals. A red blood cell suspension (washed 3 times in BSS) containing $10^{5} \mathrm{cells} / \mu \mathrm{l}$ was prepared daily.

Guinea-pig serum. Cardiac blood ( $10-15 \mathrm{ml})$ was taken from each of 6 mature, male guinea-pigs. As soon as the clot had started to form (10-15 min after bleeding) the blood was refrigerated, then the serum removed as soon as possible after centrifugation at $4^{\circ} \mathrm{C}$. The serum was absorbed at $4^{\circ} \mathrm{C}$ for $2 \mathrm{~h}$ with equal quantities of 3 times washed, packed pig and sheep red blood cells. The mixture was again centrifuged at $4^{\circ} \mathrm{C}$, the serum removed and stored at $-30^{\circ} \mathrm{C}$ in $0 \cdot 3 \mathrm{ml}$ volumes. The serum was thawed only once before use. 
Rosette formation. Rosettes were formed between pig lymphocytes and sheep red blood cells. As with human lymphocytes and sheep red blood cells, complement (i.e. guinea-pig serum) was not necessary for the formation of spontaneous rosettes. However, complement is necessary in the rosette inhibition test for maximum rosette inhibition by antilymphocyte serum (Bach et al., 1969) and for increased rosette inhibition due to the presence of EPF (Morton et al., 1977). So in the preliminary tests to determine the number of rosettes formed between pig lymphocytes and sheep red blood cells, guinea-pig serum was added. A mixture containing $1.5 \times 10^{6}$ lymphocytes in $100 \mu l$ BSS, $10^{7}$ sheep red blood cells in $100 \mu \mathrm{l}$ BSS, $50 \mu \mathrm{l}$ guinea-pig serum diluted 1 in 5 in BSS and $250 \mu \mathrm{l}$ BSS was centrifuged at $200 \mathrm{~g}$ for $5 \mathrm{~min}$ immediately after the addition of the red blood cells to the lymphocytes. After centrifugation the cells were immediately resuspended by rotation on a Matburn wheel (10 rev/min for $5 \mathrm{~min}$ ), then spread on a haemocytometer and the number of rosettes per 200 lymphocytes was counted in duplicate. A rosette was defined as a lymphocyte with 3 or more adhering red cells.

To determine the accuracy of counting rosettes, lymphocyte suspensions were prepared from 5 pigs. Ten identical mixtures were prepared (as described above) from each lymphocyte suspension and, for each, the rosettes in the ruled area of the haemocytometer $(3 \mathrm{~mm} \times 3 \mathrm{~mm} \times 0.1 \mathrm{~mm})$ were counted in duplicate, then the mean and s.d. of the 10 counts determined.

Rosette inhibition test. Antilymphocyte serum was diluted $1 \times 10^{3}$ in BSS, followed by serial double dilutions $(250 \mu$ l volumes $)$ to $256 \times 10^{6}$. Every second dilution was discarded, leaving 10 dilutions with 2 tubes containing $250 \mu \mathrm{l}$ BSS alone. To each of these 12 tubes was added $50 \mu 1$ guinea-pig serum, diluted 1 in 5 with BSS, and $100 \mu l$ lymphocyte suspension. These mixtures were incubated at $37^{\circ} \mathrm{C}$ for $1.5 \mathrm{~h}$ and were then equilibrated at room temperature for $10 \mathrm{~min}$ before the addition of $100 \mu \mathrm{l}$ sheep red blood cells. Immediately, the tubes were centrifuged at $200 \mathrm{~g}$ for $5 \mathrm{~min}$, the pellet resuspended by rotation on a Matburn wheel at $10 \mathrm{rev} / \mathrm{min}$ for $5 \mathrm{~min}$, and each suspension spread at the same time in duplicate on haemocytometers. In the ruled area of the haemocytometer, i.e. in $0.9 \mu \mathrm{l}$ suspension, the number of rosettes was counted in each spread and the average number of rosettes in each antilymphocyte serum dilution was recorded as a percentage of the number in the tubes containing BSS alone, i.e. without antilymphocyte serum. It is important to complete these steps in the minimum time possible without interruptions. The rosette inhibition titre (RIT) is defined as the highest titre of antilymphocyte serum in which the number of rosettes formed is less than $75 \%$ of the number of rosettes formed in the absence of antilymphocyte serum. This titre is recorded at $\log _{2}$ reciprocal dilution of antilymphocyte serum.

For each sample, the results of rosette formation in each antilymphocyte serum dilution were subjected to a linear regression test and the regression coefficient was determined. The antilymphocyte serum dilution to give $75 \%$ and $50 \%$ rosette formation was then calculated.

Assay for EPF. To test for EPF in serum samples, $0.2 \mathrm{ml}$ serum (diluted 1 in 2) was incubated with the pellet of lymphocytes from $1.2 \mathrm{ml}$ lymphocyte suspension for $0.5 \mathrm{~h}$ at $37^{\circ} \mathrm{C}$. The cells were then washed twice in BSS, made up to a volume of $1.2 \mathrm{ml}$ and used in the rosette inhibition test as previously described.

Identification of serum inhibiting factor. In testing the serum from the first group of pigs, some samples had shown a marked increase in RIT after dialysis (see 'Results'). To identify the factor involved, duplicate serum samples $\left(10 \mathrm{ml}\right.$ ) were dialysed (Visking dialysis membrane, $\mathbf{M}_{\mathrm{r}}$ cutoff 15 $\times 10^{3}$; Union Carbide Corp., Chicago, U.S.A.) against 1 litre phosphate-buffered saline for $24 \mathrm{~h}$. The dialysate was then concentrated to the original serum volume in a concentration-dialysis cell using an Amicon UM01 membrane (Amicon, U.S.A.).

Column chromatography. The apparent molecular weight of pig EPF was obtained by passage of pig serum through a column $(60 \times 3 \mathrm{~cm})$ of Sephacryl S-300 (Pharmacia Fine Chemicals, Sweden), calibrated using the molecular weight marker kit of Pharmacia Fine Chemicals. The column was equilibrated with $0.01 \mathrm{M}$-Tris acetate, $1.0 \mathrm{M}-\mathrm{NaCl}, 0.2 \%$ sodium azide, $0.03 \mathrm{M}$-EDTA, $\mathrm{pH} 7.4$; the volume of serum applied was $1 \mathrm{ml}$ and $3-\mathrm{ml}$ fractions were collected. Before testing, fractions were dialysed against PBS and concentrated to $1 \mathrm{ml}$. Alternate fractions were tested for EPF and the results expressed as the RIT. 
Ammonium sulphate fractionation. Serum taken from a pig $48 \mathrm{~h}$ after mating, and positive for EPF, was separated into components EPF-A and EPF-B with $40 \%$ ammonium sulphate as described by Clarke et al. (1980).

Preparation of mouse EPF-A and EPF-B. These EPF-components were produced by separate culture of oviducts and ovaries from $24-\mathrm{h}$ pregnant mice at $37^{\circ} \mathrm{C}$ for $24 \mathrm{~h}$ in RPMI. The method was as described by Morton et al. (1980).

\section{Results}

Under the conditions described in the methods, a mean of $6 \cdot 1 \%$ pig peripheral blood lymphocytes formed spontaneous rosettes with sheep red blood cells (s.e.m. $0 \cdot 31, n=30$, each assay counted $\times$ 4). The range of individual assays was 3.0 to $9.3 \%$. After $0.5 \mathrm{~h}$ incubation in non-pregnancy serum, the number of rosettes formed per 100 lymphocytes was $6.5 \%$ (s.e.m. $0 \cdot 58, n=25$ ) compared with $6.7 \%$ (s.e.m. $0 \cdot 31, n=100$ ) formed after incubation in pregnancy serum. There was no significant difference between these three means.

The results of the 5 repetitive assays gave mean \pm s.d. rosette counts of $115 \pm 10 \cdot 7,152 \cdot 8 \pm 7 \cdot 8$, $104.4 \pm 9 \cdot 0,182 \cdot 7 \pm 6 \cdot 4$ and $67 \cdot 5 \pm 5 \cdot 3$ in the ruled area of the haemocytometer, i.e. in a volume of $0.9 \mu \mathrm{l}$ suspension. By obtaining the standard error of $25 \%$ of the mean rosette count and performing a $t$ test, in each case $75 \%$ of this rosette count would be significant inhibition $(P<0.001)$.

There was a wide variation in the response of individual antilymphocyte sera tested using lymphocytes with and without preincubation in pregnancy serum taken from a sow at $48 \mathrm{~h}$ gestation (Table 1). For the present studies, antilymphocyte serum No. 247 was used since it gave inhibition as an antilymphocyte serum as well as an enhanced response due to the presence of EPF. The RIT of antilymphocyte serum No. 247, determined with lymphocytes from different male and non-pregnant female pigs, was $10 \cdot 2$ (s.e.m. $0 \cdot 14, n=20$ ), range $10-12$. With lymphocytes preincubated in non-pregnancy serum from different sows, the RIT was $10 \cdot 4$ (s.e.m. $0 \cdot 18, n=20$ ), range 10-12. The reproducibility of the method was such that an RIT of 10 or 12 was found in all assays when testing lymphocytes with or without preincubation in non-pregnancy serum. Consequently, an RIT $>12$ was considered evidence of the presence of EPF.

Representative curves of the rosette inhibition test on 3 samples, taken from pigs $48 \mathrm{~h}$ after mating, are shown in Text-fig. 1. RIT of these serum samples are 16, 20 and 24. RIT with nonpregnancy serum samples, 10 and 12, are also illustrated. The RIT has been defined as the highest serial dilution of antilymphocyte serum to give less than $75 \%$ rosette formation. The antilymphocyte serum dilution to give $75 \%$ rosette formation was also calculated from the line of regression. The mean of these values was $12 \cdot 1$ (s.e.m. $0 \cdot 27, n=20$ ) for the non-pregnancy group and $20 \cdot 4$ (s.e.m. $0 \cdot 71, n=46$ ) for the pregnancy group (see Text-fig. 4). The difference between these means

Table 1. RIT ( $\log _{2}$ reciprocal dilution) with and without pregnancy serum using different preparations of rabbit antipig lymphocyte serum

\begin{tabular}{lcccccc}
\hline & \multicolumn{6}{c}{ Antilymphocyte serum } \\
\cline { 2 - 7 } & 216 & 218 & 247 & 248 & 250 & 323 \\
\hline Non-pregnancy serum & 12 & 18 & 12 & 10 & 12 & 10 \\
Pregnancy serum & 30 & 34 & 20 & 28 & 14 & 10 \\
\hline
\end{tabular}

Pregnancy serum was from a sow at $48 \mathrm{~h}$ gestation and each assay was performed in duplicate. Antilymphocyte serum was considered suitable for detection of EPF if the RIT was 2 or more dilutions greater in the presence of EPF. 


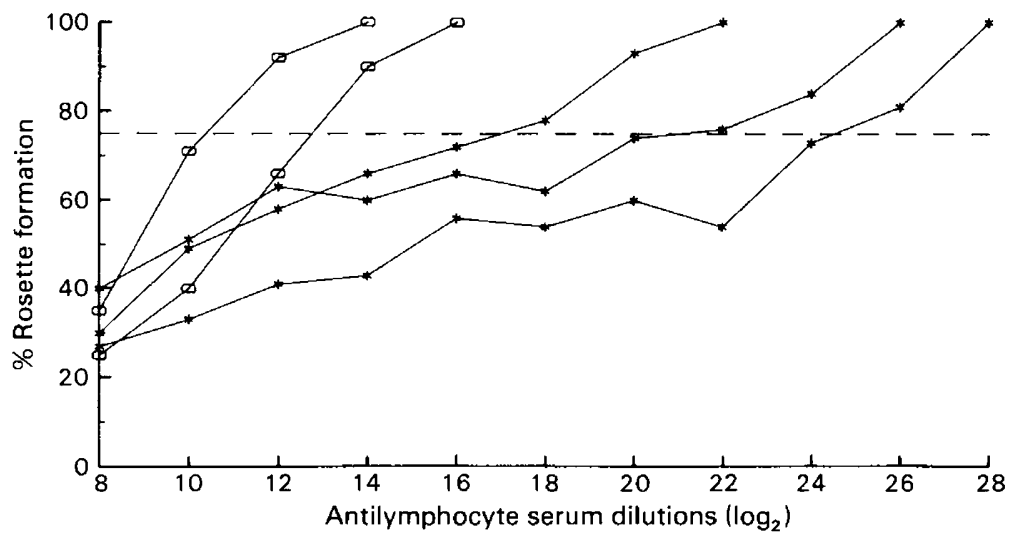

Text-fig. 1. Titration curves for rosette formation with lymphocytes, previously incubated in non-pregnancy $(\mathrm{O}-\mathrm{O})$ and pregnancy $(*-*)$ serum. Non-pregnancy serum samples were collected from 2 sows before mating and pregnancy serum samples from 3 sows, $48 \mathrm{~h}$ after mating. The antilymphocyte serum dilutions are represented as the logarithm (base 2) of the reciprocal of the dilution. The number of rosettes formed in each dilution of antilymphocyte serum is expressed as a percentage of the number of rosettes formed without antilymphocyte serum (control). The RIT of each serum sample is the highest dilution of antilymphocyte serum to give $<75 \%$ rosette formation; with the non-pregnancy samples RITs are 10 and 12 and with the pregnancy samples, 16,20 and 24 .

was significant $(P<0.001$, variation of Behrens-Fisher Test; Cochran, 1967). However, if this value was calculated for $50 \%$ rosette formation, the mean of the non-pregnancy group was $9 \cdot 1$ (s.e.m. $0 \cdot 37)$ and of the pregnancy group was $11.0($ s.e.m. 1.14). These values are not significantly different.

To determine whether EPF was detectable in a variety of molecular weight forms as in other species, serum from a sow obtained 2 days after mating was examined by gel filtration and fractions tested for their RIT. EPF could be resolved into 5 peaks of activity corresponding to apparent molecular weights of $450000,250000,90000,45000$ and 20000 with the predominant forms being of the higher molecular weight (Text-fig. 2a).

Pig EPF (from a serum sample taken at $24 \mathrm{~h}$ post coitum) could be separated into EPF-A (supernatant) and EPF-B (precipitate) by addition of $40 \%$ ammonium sulphate. These separated components had no rosette-inhibiting activity but RIT values similar to those of the original sample were obtained when pig EPF-A and EPF-B were combined with mouse EPF-B and EPF-A respectively (Table 2 ).

Table 2. RIT obtained after combining EPF components prepared from pig and mouse EPF

\begin{tabular}{|c|c|c|c|c|c|}
\hline & BSS & Pig EPF-A & Pig EPF-B & $\begin{array}{c}\text { Pig recombinant } \\
\text { (EPF-A + EPF-B) }\end{array}$ & $\begin{array}{c}\text { Concentrated } \\
\text { dialysate from } \\
\text { pig pregnancy } \\
\text { serum }\end{array}$ \\
\hline BSS & 10 & 10 & 10 & 20 & 10 \\
\hline Mouse EPF-A & 10 & 10 & 18 & - & 10 \\
\hline Mouse EPF-B & 10 & 20 & 10 & -.. & 26 \\
\hline $\begin{array}{l}\text { Mouse recombinant } \\
\text { (EPF-A + EPF-B) }\end{array}$ & 18 & - & - & - & - \\
\hline $\begin{array}{l}\text { Concentrated } \\
\text { dialysate from pig } \\
\text { pregnancy serum }\end{array}$ & 10 & 10 & 26 & - & - \\
\hline
\end{tabular}

The RIT of all recombinant preparations was assayed with pig lymphocytes. The values given are the means of duplicate assays and an RIT $>12$ is evidence of the presence of EPF. 


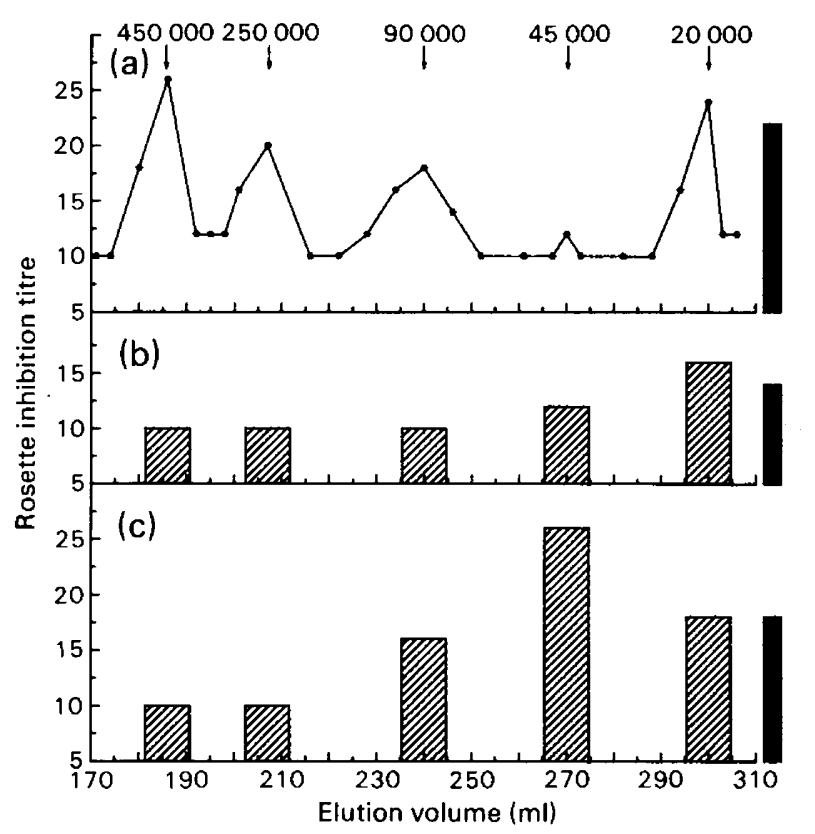

Text-fig. 2. (a) Elution profile of EPF activity obtained by passage of serum from a $48 \mathrm{~h}$ pregnant sow through a Sephacryl 300 gel fractionation column. $\square$ Pooled fractions of peak EPF activity in serum from the same sow at (b) 3 weeks and (c) 2 months of pregnancy are also shown. Fractions were tested for EPF and the results expressed as RIT. $\square$ RIT of serum samples before fractionation. RIT $>12$ is evidence of the presence of EPF. The results represent the mean of duplicate assays. The column was calibrated with the following standard proteins, ferritin $\left(M_{r} 440000\right)$, catalase $\left(M_{r} 232000\right)$, albumin $\left(M_{r} 67000\right)$, ovalbumin $\left(M_{r}\right.$ $43000)$ and chymotrypsinogen $\left(M_{r} 25000\right)$.

Of an initial 35 post-coital serum samples taken within the first 2 weeks after mating and tested for the presence of EPF, only $43 \%$ gave an RIT > 12, corresponding to the presence of EPF. It was suspected that there was some factor present in the serum which was interfering in the assay. This supposition was confirmed when dialysis of the serum gave titres comparable to those obtained after gel filtration (see Text-fig. 2) and a comparison of the serum sample titres before and after dialysis is shown in Text-fig. 3. All samples were thereafter routinely dialysed before testing.

To establish the identity of the inhibitory factor responsible for the low and erratic titres during the early stages of pregnancy, a concentrated dialysate, prepared from pooled samples shown to have an increased titre after dialysis, was tested in the presence and absence of added EPF-B. Neither EPF-B nor the concentrated dialysate gave a titre for EPF when incubated alone with lymphocytes. However, addition of the dialysate and EPF-B together gave an RIT of 26, demonstrating that the inhibitory factor was EPF-A. This result was the same irrespective of whether the EPF-B was obtained by ammonium sulphate fractionation of the same pig serum sample from which the concentrated dialysate was obtained or from culture of mouse ovaries (Morton et al., 1980) (Table 2).

To follow the time course of EPF production, 10 sows were tested before mating and at various intervals after mating, as shown in Text-figs 4 and 5. Before mating there was no increased RIT in any of the sows but peak levels of EPF were detected $24-48 \mathrm{~h}$ after mating. While there was a marked decline in the RIT around 3 weeks, EPF persisted virtually throughout the entire pregnancy in the 8 animals which subsequently farrowed successfully. After parturition, RIT 


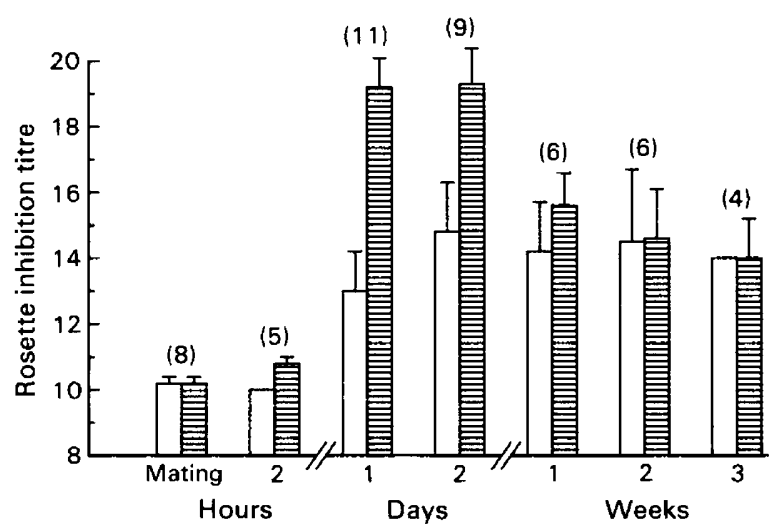

Text-fig. 3. RIT (mean with s.e.m. for the no. pigs indicated) with serum samples tested before $\square$ and after : dialysis at various times after mating. RIT $>12$ is taken as evidence of the presence of EPF.

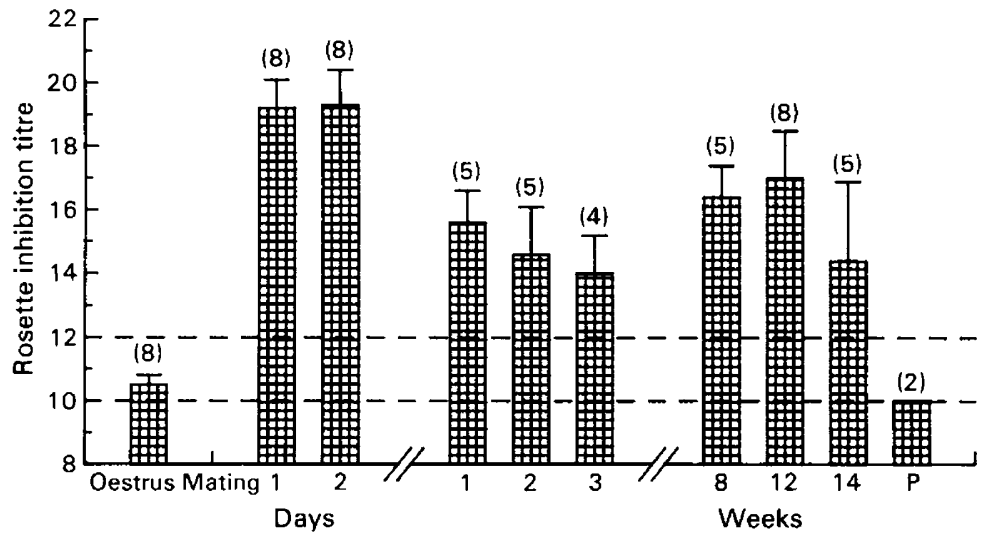

Text-fig. 4. RIT (mean with s.e.m. for the no. of animals indicated) with serum samples taken from sows before and at various times after mating; mating was 24-48 $\mathrm{h}$ after detection of oestrus and all animals farrowed (P) at the expected time. Broken lines indicate an RIT of 10 or 12 obtained with non-pregnancy serum samples.

values were within normal non-pregnancy levels. Two of the sows showed an early increased RIT but subsequently returned to oestrus; the results in Text-fig. 5 show that by 3 weeks the RIT had also declined to non-pregnancy levels.

To test whether the low titres found at the mid-stages of pregnancy reflected the comparative absence of EPF or the presence of further interference with the assay, a serum sample from a sow with low titres at 3 weeks was fractionated by gel filtration and the pooled fractions corresponding to the peaks of activity (see Text-fig. 2a) were tested for EPF. The results in Text-fig. 2(b) suggest that there were no further inhibitory factors responsible for the low titre. Text-figure 2 compares the molecular weight profile of samples taken from the same pig $48 \mathrm{~h}, 3$ weeks and 8 weeks after mating. 


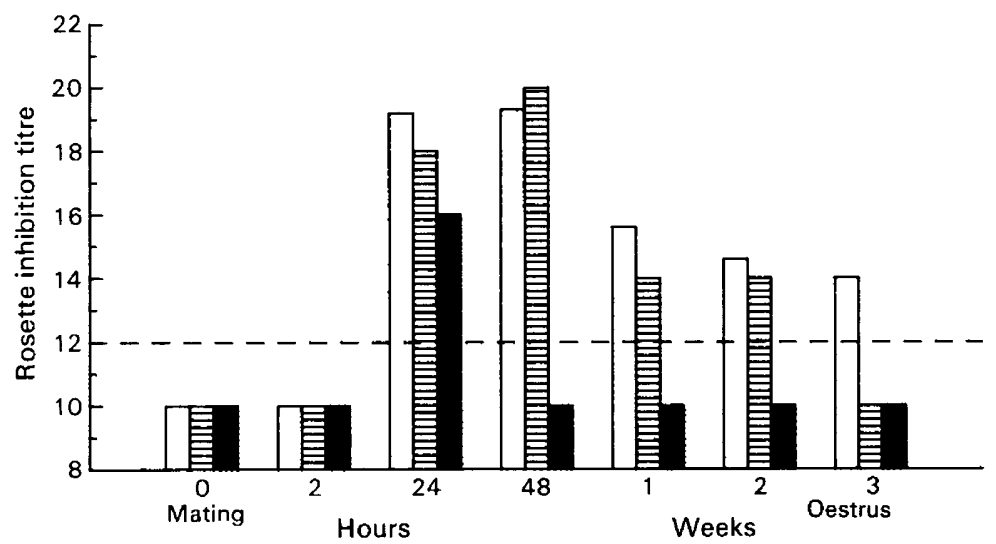

Text-fig. 5. RIT with serum samples of sows which returned to oestrus 26 days 目 and 21 days after mating. RIT with serum samples of the pregnant sows, illustrated in Text-fig. 4, are shown for comparison $\square$. The broken line indicates an RIT of 12. Any value greater than this is evidence of the presence of EPF.

\section{Discussion}

The appropriate conditions for the assay of EPF in the pig using the rosette inhibition test have now been established. The primary requirement for the assay is an effective antilymphocyte serum which gives rosette inhibition further enhanced in the presence of EPF. There is a wide variation in the response of different animals in the production of antilymphocyte serum which presumably reflects the different responses to cell surface antigens present on the lymphocyte. This is consistent with the ability of a limited number of monoclonal antibodies, notably anti-human Lyt 3, to replace antilymphocyte serum in the rosette inhibition test to detect EPF (Morton, Tinneberg, Rolfe, Wolf \& Mettler, 1982a).

The precautions previously noted for the assay of human EPF (Morton et al., 1982a) apply with equal force for the pig assay system. The rosettes involved in the present test are active or spontaneous rosettes, also called fast rosettes, which are formed immediately after the addition of sheep red blood cells to lymphocytes (Felsburg et al., 1976). These rosettes in the pig occur to the extent of about $30-100$ rosettes per 1000 lymphocytes; the number may be enhanced by the addition of dextran (Binns, 1978), bovine serum albumin or incubation of the lymphocyte/sheep red cell mixture (Escajadillo \& Binns, 1975). However, these enhanced rosettes do not respond to the presence of antilymphocyte serum in the assay for EPF (Morton et al., 1982a). Some confusion has arisen when other lymphocyte rosetting methods have been used in the assay (Thomson, Milton, Campbell \& Horne, 1980; Cooper \& Aitken, 1981) but an explicit description of active rosettes with the appropriate conditions for their formation has been provided (Bach et al., 1969).

The full expression of rosette-inhibiting activity depends on an initial dialysis of the serum to remove the inhibitory effect of the presence of excess activated EPF-A. Previous studies have demonstrated that EPF-A is the moiety of the EPF complex which determines binding to lymphocytes, presumably to a receptor (Clarke et al., 1980; Morton et al., 1980). The inhibitory effect of EPF-A when present in an unassociated form would then be explained by competition between EPF-A and EPF for binding to this receptor. In the mouse, EPF-A has been shown to be produced by the oviduct during oestrus and during subsequent pregnancy (Morton et al., 1980). There are several aspects of the concurrent appearance of free EPF-A with EPF during early pregnancy in pigs that warrant comment. The fact that free EPF-A occurs in about half the samples of pig serum tested indicates differences between individual pigs. Further the production of EPF-B does not 
appear to be regulated by the presence of EPF-A. The known factors involved in the production of EPF-B by the ovaries in the mouse are prolactin and ovum factor, the latter coming from the zygote (Cavanagh et al., 1982); under certain conditions, i.e. those known to stimulate parthenogenetic activation, the unfertilized ovum may also be triggered to release ovum factor (Cavanagh et al., 1982).

Apart from the presence of excess activated EPF-A, the other novel aspect of EPF in the pig is its persistence virtually throughout the entire pregnancy. In other species, there is an early production of EPF which is present with steadily declining levels for the first two-thirds of pregnancy and thereafter may be absent (Morton et al., 1977; Morton, Clunie \& Shaw, 1979b; Morton, Rolfe \& Cavanagh, 1982b). In the pig there appears to be a biphasic production of EPF with a second surge of production later in pregnancy. This may suggest that there is possibly more than one site of EPF production or that there is a shift in the regulation of EPF during the last month of pregnancy. The present study has not sought to focus upon the time of the first appearance of EPF which must await a more detailed study. However, it seems likely that it can be demonstrated within $24 \mathrm{~h}$ of mating, as with the other species so far tested (Morton et al., 1979a; Smart, Roberts, Clancy \& Cripps, 1981; Rolfe, 1982).

The fact that it was possible to hybridize EPF-A from the pig with EPF-B from another species to give full activity in vitro is in keeping with the lack of species specificity of EPF action on lymphocytes. This genetically unrestricted activity allows the use of the lymphocyte/antilymphocyte serum system from an entirely different species to be used for the detection of EPF, providing other interfering serum proteins are first removed.

At present the role which has been proposed for EPF is one of immuno-modulation based upon the ability of EPF to inhibit the expression of an immune response in vivo (Noonan, Halliday, Morton \& Clunie, 1979). It has been suggested, therefore, that EPF may prevent the maternal recognition of the alien antigenic status of the embryo (Morton et al., 1976). That EPF-A is able to modify the lymphocyte response to EPF clearly deserves further investigation from this aspect.

We thank Ms I. Daniel for expert assistance throughout this work, Mr I. Morton for the computer graphics and Dr P. Jones, C.S.I.R.O. Division of Mathematics and Statistics, for help in the statistical analysis. This work was supported in part by a grant from the German Research Council (DFG).

\section{References}

Bach, J.F., Dormont, J., Dardenne, M. \& Balner, H. (1969) In-vitro rosette inhibition by anti-human ALS. Transplantation 8, 265-280.

Binns, R.M. (1978) Sheep erythrocyte rosettes in pigs, sheep, cattle and goats demonstrated in the presence of dextran. J. Immunol. Methods 21, 197-210.

Cavanagh, A.C., Morton, H., Rolfe, B.E. \& Gidley-Baird, A.A. (1982) Ovum factor: a first signal of pregnancy? Am. J. Reprod. Immun. 2, 97-101.

Clarke, F. \& Wilson, S. (1982) Biochemistry of early pregnancy factor. In Pregnancy Proteins, pp. 407-412. Ed. J. G. Grudzinskas. Academic Press, Sydney.

Clarke, F.M., Morton, H., Rolfe, B.E. \& Clunie, G.J.A. (1980) Partial characterisation of early pregnancy factor in the sheep. J. Reprod. Immun. 2, 151-162.

Cochran, W.G. (1967) Statistical Methods, 6th edn, pp. 114-119. Eds G. W. Snedecor \& W. G. Cochran. Iowa State University Press, Ames.

Cooper, D.W. \& Aitken, R.J. (1981) Failure to detect altered rosette inhibition titres in human pregnancy serum. J. Reprod. Fert. 61, 241-245.
Ellendorff, F., Parvizi, N., Elsaesser, F. \& Smidt, D. (1977) The miniature pig as an animal model in endocrine and neuroendocrine studies of reproduction. Lab. Anim. Sci. 27, 822-830.

Escajadillo, C. \& Binns, R.M. (1975) Rosette formation of pig T lymphocytes with sheep erythrocytes. Int. Archs Allergy appl. Immun. 49, 325-331.

Felsburg, P.J., Edelman, R. \& Gilman, R.H. (1976) The active $E$ rosette test: correlation with delayed cutaneous hypersensitivity. $J$. Immunol. 116, 11101114.

Hultsch, K.H. \& Ellendorff, F. (1979) A new technique for blood sampling in pigs. Dt. tierärztl. Wschr. 86, 293-332.

Morton, H., Hegh, V. \& Clunie, G.J.A. (1976) Studies of the rosette inhibition test in pregnant mice : evidence of immuno-suppression? Proc. R. Soc. B 193, 413-419.

Morton, H., Rolfe, B., Clunie, G.J.A., Anderson, M.J. \& Morrison, J. (1977) An early pregnancy factor detected in human serum by the rosette inhibition test. Lancet i, 394-397. 
Morton, H., Nancartow, C.D., Scaramuzzi, R.J., Evison, B.M. \& Clunie, G.J.A. (1979a) Detection of early pregnancy in sheep by the rosette inhibition test. $J$. Reprod. Fert. 56, 75-80.

Morton, H., Clunie, G.J.A. \& Shaw, F.D. (1979b) A test for early pregnancy in sheep. Res. vet. Sci. 26, 261 262.

Morton, H., Rolfe, B.E., McNeill, L., Clarke, P., Clarke, F.M. \& Clunie, G.J.A. (1980) Early pregnancy factor: tissues involved in its production in the mouse. $J$. Reprod. Immun. 2, 73-82.

Morton, H., Tinneberg, H.-R., Rolfe, B.E., Wolf, M. \& Mettler, L. (1982a) Rosette inhibition test: a multicenter investigation of early pregnancy factor in humans. J. Reprod. Immun. 4, 251-261.

Morton, H., Rolfe, B. \& Cavanagh, A. (1982b) Early pregnancy factor: biology and clinical significance. In Pregnancy Proteins, pp. 391-405. Ed. J. G. Grudzinskas. Academic Press, Sydney.
Noonan, F.P., Halliday, W.J., Morton, H. \& Clunie, G.J.A. (1979) Early pregnancy factor is immunosuppressive. Nature, Lond. 278, 649-650.

Rolfe, B.E. (1982) Detection of fetal wastage. Fert. Steril. 37, 655-660.

Rolfe, B.E., Morton, H. \& Clarke, F.M. (1983) Early pregnancy factor is an immunosuppressive contaminant of commercial preparations of human chorionic gonadotrophin. Clin. exp. Immunol. 51, 45-52.

Smart, Y.C., Roberts, T.K., Clancy, R.L. \& Cripps, A.W. (1981) Early pregnancy factor: its role in mammalian reproduction-research review. Fert. Steril. 35, 397401.

Thomson, A.W., Milton, J.I., Campbell, D.M. \& Horne, C.H.W. (1980) Rosette inhibition levels during early human gestation. J. Reprod. Immun. 2, 263-268.

Received 10 January 1983 